\title{
NATAL DISPERSAL AND POPULATION STRUCTURE IN A MIGRATORY SONGBIRD, THE INDIGO BUNTING
}

\author{
ROBERT B. PAYNE \\ Museum of Zoology and Department of Biology, The University of Michigan, \\ Ann Arbor, MI 48109 USA
}

\begin{abstract}
Male and female indigo buntings (Passerina cyanea) were equally likely to return and breed in their natal areas. The distances and number of territories between natal and breeding sites were similar between the sexes. The breeding site was not limited by prior occupation of sites by breeding adults closer to the natal territory. Dispersal distances were independent of whether parents or siblings of either sex returned in the same year. Variation in distance within the natal area appeared to be independent of local population density, social competition, active kin recognition, and avoidance of incest, but was affected by date of birth. The local distribution of dispersal distances approximated a neutral model with a decreasing probability of settling with distance from the natal site.

A population inbreeding coefficient $\Delta \mathrm{F}$ of 0.01 was estimated from known genealogies and matings. The proportion of nestlings recaptured in a later year on their natal area was $1.65 \%$ of 1,212 nestlings at the George Reserve and $8.78 \%$ of 1,332 nestlings at Niles. Locally born birds comprised $1.6 \%$ and $13.0 \%$ of the breeding population in areas of 10 and $4 \mathrm{~km}^{2}$. Evidently most buntings settle and breed more than $2 \mathrm{~km}$ from their natal site. The results are inconsistent with predictions of social and avoidance-of-inbreeding hypotheses that are based on the local natal demographic environment. The results are consistent with a model of neutral dispersal within a genetically open population.
\end{abstract}

Received April 19, 1989. Accepted July 28, 1990.

Natal dispersal is the net movement between the site of birth and the site of breeding, and it determines the extent of gene flow and the population structure. Dispersal can maintain genetic continuity among populations and the integrity of biological species (Mayr, 1963; Wright, 1969, 1978; Endler, 1977; Gauthreaux, 1978; Barrowclough, $1980,1983)$. On a more local scale, natal dispersal can influence or be determined by (1) social competition, and (2) the incidence and fitness effect of inbreeding (Wright, 1969; Greenwood et al., 1979; Greenwood, 1980; Shields, 1982; Bateson, 1983; Ralls et al., 1986; Pusey, 1987; Chepko-Sade and Halpin, 1987; Charlesworth and Charlesworth, 1987).

The hypothesis that natal dispersal is an adaptive behavior for avoiding inbreeding involves predictions that inbreeding individuals have lower reproductive success, and dispersal is necessary as well as sufficient for inbreeding avoidance. An alternative hypothesis is that social competition forces individuals to leave their natal area (Moore and Ali, 1984; De Laet, 1985). The social competition hypothesis has guided studies of resource supplementation; observations and experiments suggest that sex-biased dis- persal is independent of resource availability (Dobson and Jones, 1985), and other observations suggest attraction of one sex by the other in neighboring groups rather than aggressive exclusion by the same sex (Greenwood, 1980; Pusey, 1987; CluttonBrock, 1989). The inbreeding avoidance and social competition hypotheses do not include all possibilities, nor do they necessarily lead to alternative predictions (Dobson and Jones, 1985). Genealogical relationships among individuals might affect both mate choice and social competition, and so may affect the site where individuals breed. Social structure can affect population genetics (Chepko-Sade and Halpin, 1987) and vice versa (Stenseth, 1984).

Dispersal may also be described with neutral models. A neutral model implies that variation in natal dispersal distances is independent of the social environment of individuals, though it does not explain the mechanisms leading to the variation. A neutral model would be indicated by a decrease in density of dispersers with distance from the natal site; in other words, it predicts an ideal free distribution where the distance from birth to breeding is not constrained by other individuals (Lotka, 1956; 
Fretwell and Lucas, 1969). Neutral models have been used widely in descriptions of dispersal (MacArthur and Wilson, 1967; Wright, 1978; Okubo, 1980; Taylor, 1980; Sellers, 1984). Some models that incorporate random movement from a natal site assume exclusive occupancy of breeding sites through social competition (Murray, 1967; Waser, 1985, 1987) and are not neutral in the present sense.

Predictions of these hypotheses can be tested in the variation observed among individuals in a local population. I. Inbreeding avoidance. (1) inbreeding is rare, (2) inbreeding is disadvantageous, (3) one sex disperses more than the other, and (4) individuals with relatives of the opposite sex with which they might breed settle further from their natal site than individuals without close kin. Inbreeding may be rare either due to active avoidance or as an incidental result of dispersal. Also, inbreeding depression may be necessary but not sufficient to lead to dispersal (van Tienderen and van Noordwijk, 1988). A prediction of the first breeding site depending on the presence of close kin implies active kin recognition, which might be expected if inbreeding is disadvantageous. II. Social competition. (1) adults arrive earlier and exclude first-year birds from returning to their natal sites, (2) dispersal is determined by social conditions of early life, including hatching date and competition among siblings, and (3) dispersal of individuals with surviving local relatives of the same sex is greater than in individuals with no such relatives. The last, like prediction I(4), implies active kin recognition. III. A neutral model of dispersal. (1) no predictions of the other proximate models are supported with field observations, (2) a cumulative probability distribution accounts for the observed dispersal distances, and (3) dispersal distances and effective population sizes are large and scale beyond the local effects described in the other models, with most birds breeding well beyond their natal area and most breeding birds immigrating from other natal areas. The predictions were tested in observations of genealogies, dispersal histories, and breeding consequences in local populations of a small migratory songbird, the indigo bunting (Passerina cyanea).

\section{MeTHODS}

Study Areas. - Indigo buntings were observed from 1978 through 1988 in southern Michigan (Payne, 1982, 1989; Payne and Payne, 1989; Payne and Westneat, 1988; Payne et al., 1987, 1988). One study area was located at the E. S. George Reserve and the neighboring Pinckney State Recreation Area $\left(42^{\circ} 27^{\prime} \mathrm{N}, 84^{\circ} 00^{\prime} \mathrm{W}\right)$. The habitat comprised equal areas of woodland, old fields on farmland abandoned since the 1920's, and shrubby swamps. The other was near Niles $\left(41^{\circ} 55^{\prime} \mathrm{N}, 86^{\circ} 14^{\prime} \mathrm{W}\right)$ on shrubby roadsides and railway rights-of-way, an abandoned railway terminal, secondary woodland, old fields, and farmlands with maize and soybeans.

The "study area" where breeding was determined was part of a larger "natal area" extending $0.2-1.0 \mathrm{~km}$ around it where searches were completed for dispersing buntings. The sizes of the areas were determined by our efforts in the field and success in locating nearly all the buntings and their nests. The areas were increased each year in the first six years and maintained in the later years to include more birds and to find dispersing birds. The study area at the George Reserve was extended from 6 to 10 $\mathrm{km}^{2}$, when 1,080 ha were under equally close observation and the longest dimension was $4,500 \mathrm{~m}$. The area at Niles was extended from 1.4 to $4 \mathrm{~km}^{2}$, when 406 ha were checked through the season for nesting, 700 ha were checked for banded birds, and the longest dimension was $3,750 \mathrm{~m}$. Locations of birds were determined by comparing field observations with maps and aerial photographs.

Field Methods. - Within a study area more than $95 \%$ of the breeding males and about $50 \%$ of the breeding females were colorbanded, nearly all nests were found, and the nestlings were banded (Payne, 1982, 1989; Payne et al., 1988). Males were captured with playback of a recorded song and attraction to a dummy male near a mist net. All were defending their singing site and were territorial. Females were netted at the nests. The plumages of first-year and adult birds were determined by comparison with males of known age (banded as nestlings). Males in their first spring have one or more brown greater primary coverts. Older males 
have all blue greater primary coverts. Most buntings had territories smaller than 1 ha. Each area had more than 100 resident, territorial males. Because the areas were convex and large, most birds were far from the margin of the study area. Local movements to a territory nearby but off the study area were likely only for a few marginal territories and nearly all territories were surrounded by other bunting territories.

Nestlings were banded between 4 and 8 days after hatching; the young fledge from the nest at 9-10 days. A few were banded as short-tailed fledglings in the care of the adults on their natal territories, three of these returned and were included as returning nestlings. The parents were determined by observation of the male that defended the territory and the female that attended the young.

Analytical Techniques. - Mean dispersal distances were compared with $t$-tests and analyses of variance (ANOVA, $F$-tests); the distances were log-transformed for these tests. Distances less than $100 \mathrm{~m}$ were accurate within $10 \mathrm{~m}$, and longer distances were estimated as the diagonal between the center of the natal grid and the first breeding grid with a $100-\mathrm{m}$ grid on the maps. The number of territories between the natal site and first breeding site was 0 if the territories overlapped, otherwise it was the number between the two plus the territory of the returning nestling.

\section{RESUlts}

Natal Returns and Local Dispersal. -Indigo buntings are migrants, moving from their breeding grounds in temperate North America to winter in tropical areas of Mexico and Central America. Some birds return and breed in their natal area. Of 2,544 nestlings that were banded and survived to fledging from 1977 through 1987, 137 (5.4\%) were recovered in a later breeding season. Nearly all recoveries in a year after birth (135) were found from May through August within $3 \mathrm{~km}$ of the nest site where they were reared. The rate of recovery or return of banded nestlings that had survived to fledge was $1.7 \%$ at the George Reserve ( 20 of 1,212 nestlings) and $8.8 \%$ at Niles (117 of 1,332 nestlings). Males were captured when they were actively defending their territory, and most of them nested at least once in their natal area. All females recovered after they were banded as nestlings were nesting. The recoveries of young in a later year involve breeding birds and so are genetically effective dispersals.

The other recoveries were distant, two males banded as nestlings at the Reserve in 1984 and recovered in May 1985. One was $52 \mathrm{~km}$ from its natal site, the other was 350 $\mathrm{km}$, and both were at their natal latitude. By this date many local first-year males (including a nestmate of the male recovered at $350 \mathrm{~km}$ ) had settled on territories on the study area, and the two distant males may have been at a breeding site outside their natal area.

Buntings banded as nestlings and found in their natal area in a later year included 18 at the Reserve and 117 at Niles. At the Reserve, nine males and nine females were recaptured in their natal area. At Niles, 68 males and 49 females were recaptured in a later breeding season. Several (10 males, 8 females) were third-generation birds with one or both parents having been banded as a nestling in the same natal area, and one was a fourth-generation Niles bird.

Most returning nestlings were found as yearlings. The birds captured in a later year either appeared within the study area or nearby, and two yearlings were found just outside the study area. In birds discovered after their first year, three males and one female were outside the study area, the males as they sang and the female when the area was checked for nesting. The others (seven males, seven females) were found as adults in the study area two years after birth and were not there as yearlings as the field census was reasonably complete (Payne et al., 1988). A male might escape notice if it remained for fewer than four days, and a female if it did not remain and breed. The analyses of distances are restricted to birds observed as yearlings. For each returning local bunting that was first observed on the study area in a later year, and not as a yearling, another returning bunting that was on the study area as a yearling may have emigrated to breed elsewhere in a later year. Fifty additional buntings were observed within $1 \mathrm{~km}$ of the study area in both 1984 

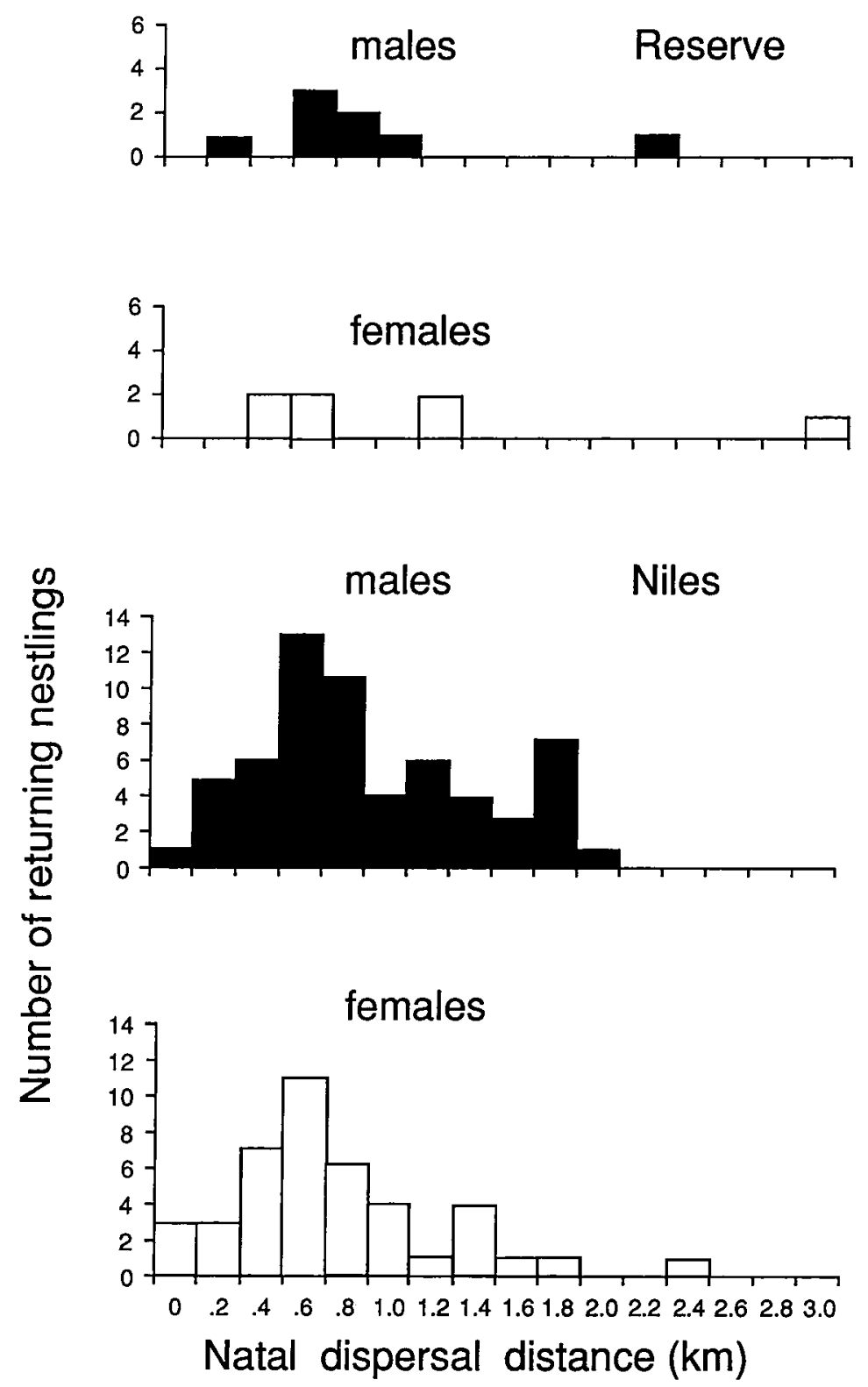

FIG. 1. Histogram of local distances between natal site and first breeding site of yearlings in two populations of indigo buntings.

and 1985. Only two of these birds had been banded as nestlings.

Incidence of Male and Female Returns to the Natal Area. - From 1979 through 1988, 65 first-year males and 49 first-year females that were banded as nestlings in the previous year were recaptured on the two study areas. The incidence of returning males and females did not differ significantly from a
1:1 distribution (binomial test, $z=0.004$, $P>0.95$ ). Similar numbers of males and females returned within each natal area, allowing for differences in detectability: males perch conspicuously and attract attention by singing, while females are not often seen until the observer finds their nests.

Dispersal Distances. - Natal dispersal was compared for birds in the year after they 


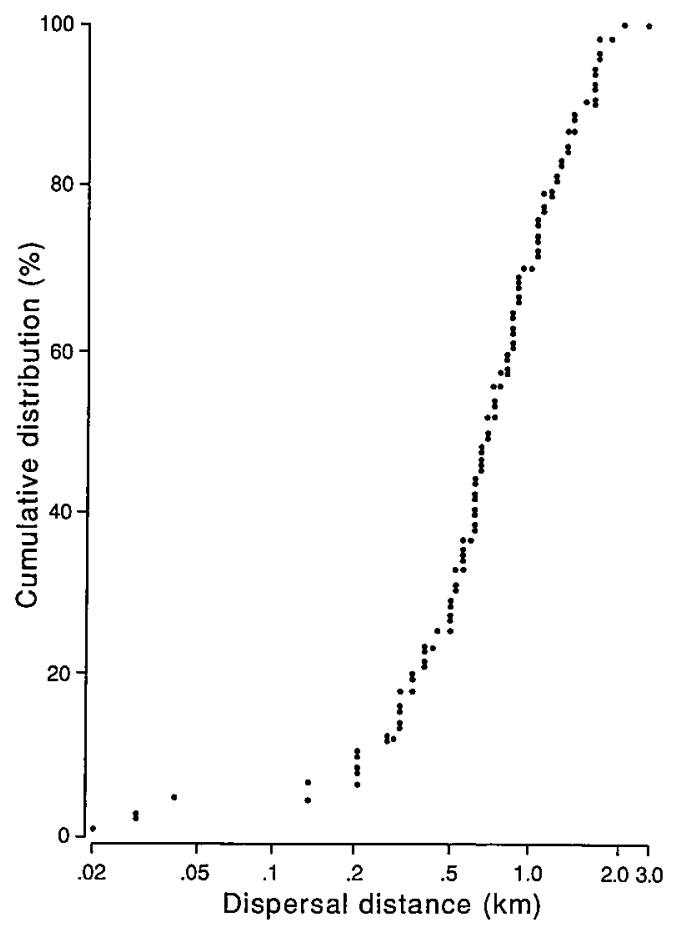

FIG. 2. Cumulative frequency distribution of natal dispersal distances in yearling indigo buntings ( 115 birds settling on their natal area), semilog plot.

were banded as nestlings (Fig. 1). The distances $(\mathrm{m})$ did not differ between the sexes (Reserve, males, mean $=937 \pm 659 \mathrm{SD}$, females, mean $=708 \pm 427 \mathrm{SD}, t=0.86$, NS; Niles, males, mean $=870 \pm 512 \mathrm{SD}$, females, mean $=708 \pm 427 \mathrm{SD}, t=0.86$, NS). Natal dispersal distances were similar in the two areas (Reserve, mean $=985 \pm$ $580 \mathrm{SD}$; Niles, mean $=802 \pm 430 \mathrm{SD}, t=$ 0.93 , NS).

The cumulative distribution of distances indicates a linear relationship with the $\log$ of distance from the natal site from 200 to 2,000 m (Fig. 2). At shorter distances, other buntings on territories might influence whether a bunting settles. At distances beyond $2,000 \mathrm{~m}$ the chance of finding a bird is low, and the curve in the upper $10 \%$ of the observed distances suggests a truncation of detectable distances by the finite study area.

Within the middle $80 \%$ of the distance ranks (excluding the highest and lowest $10 \%$, and including $N=84$ from the total of 117 distances), the cumulative incidence of set- tling increased with distance from the natal site, and density of settling decreased as a negative exponential with log-transformed distance $\left(b=0.77, r^{2}=0.96\right)$. Figure 2 suggests a linear decrease in density of dispersers with an increasing area defined by distance from the natal site in a distribution described by the expression, $N=\int_{0}^{x} 2 \pi \rho(x)$ $\mathrm{x} d x$, where $N$ is the total number of birds in the population derived from a natal site, density is integrated from the natal site to an undetermined most distant site $x$, and $\rho$ is the density of these birds in distance interval $d x$ from the natal site. Other buntings may return and settle outside the observed range of distances, but the distribution of these distances is unknown.

Dispersal also was compared for the numbers of territories from the natal site to the first breeding site. Territories were mapped in the year when the bird returned as a yearling. Dispersal was determined by counting territories within a $100-\mathrm{m}$ wide path of suitable habitat between the natal and breeding territories, or along the nearest suitable habitat where the territories were separated by more than $400 \mathrm{~m}$ and a direct path was over uninhabited farmland. Territory size varied from 0.4 ha in shrubby areas to 8 ha in swamps (Payne, 1989). The number of territories between natal and first breeding sites was greater at Niles than at the Reserve (Fig. 3) (Reserve, $N=13$, mean $=4.64 \pm 3.40 \mathrm{SD}$; Niles, $N=100$, mean $=7.56 \pm 4.27 \mathrm{SD}, t=2.39, P<0.05$ ). Within an area, settlement did not differ between the sexes (Reserve, males, $N=6$, mean $=4.33 \pm 2.58 \mathrm{SD}$, females, $N=7$, mean $=4.86 \pm 4.18 \mathrm{SD}, t=0.27$, NS; Niles, males, $N=58$, mean $=7.98 \pm 4.05$, females, $N=42$, mean $=6.98 \pm 4.54 \mathrm{SD}, t$ $=0.86, \mathrm{NS})$. The difference between areas is explained by habitat: territories are smaller and the habitat is more filled at Niles than at the Reserve, so the same distance involves more territories at Niles.

Nestling Condition and Dispersal Distances. - Natal dispersal distances were compared with the condition of the buntings as nestlings, where condition may have affected their social status. Dates of hatching were observed by checking nests near the time of hatching. The hatching dates of buntings banded as nestlings and returning 


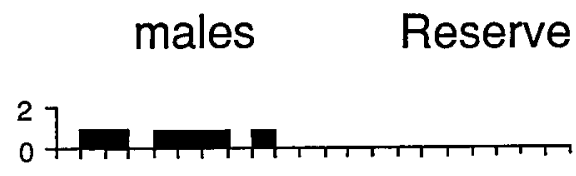

females

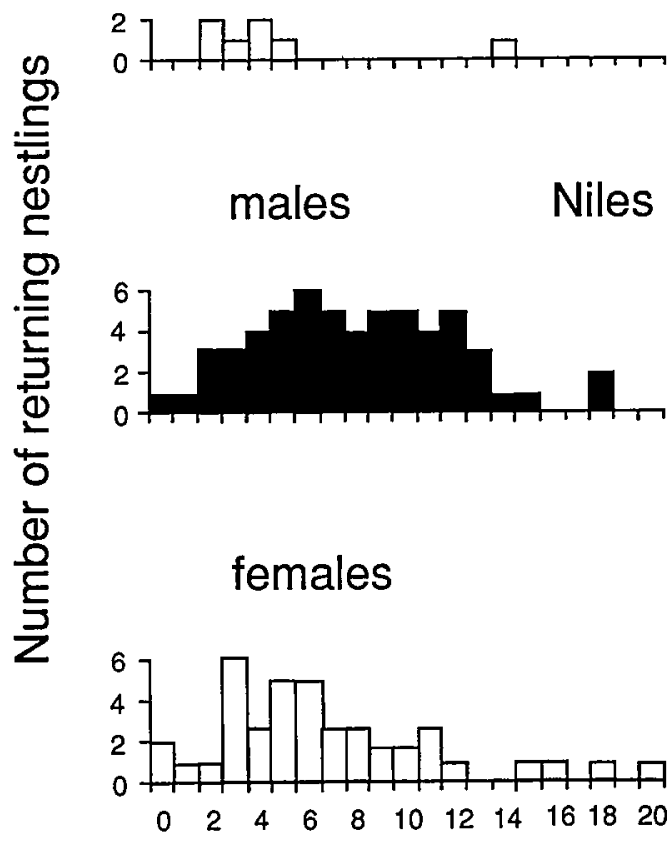

\section{$\mathrm{N}$ territories, natal to breeding}

FIG. 3. Histogram of number of territories moved from natal site to first breeding site in yearling indigo buntings.

to their natal area were from 6 June to 22 August, a range of 77 days, nearly as large as the range ( 85 days) for all successful nests. Natal dispersal distance within the natal area was negatively related to the date of hatching at Niles $\left(N=100, b=-0.01, r^{2}=0.05\right.$, $\left.F_{[1,98]}=5.34, P<0.01\right)$. The effect was significant but it explained only $5 \%$ of the variance in distance. Separate analyses of males and females at Niles showed no significant association of dispersal distance and date. In both sexes the birds born later returned closer to the natal site, and hatching date explained more than $10 \%$ of the variance in distance in each sex. A tendency of late fledglings to return to the natal area may lead to the association of distance and birth

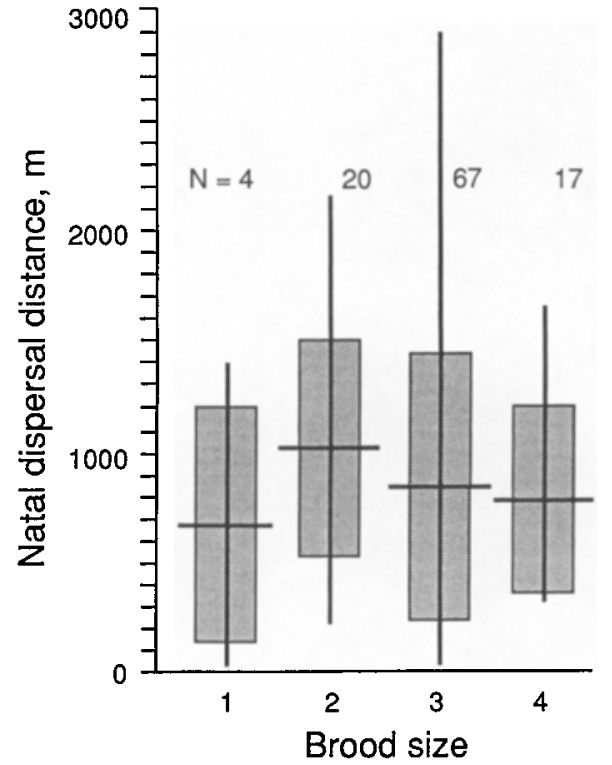

Fig. 4. Natal dispersal distance in relation to natal brood size. The figure indicates mean, SD, and range of distance $(\mathrm{m})$.

date, as the early-hatched birds would be more likely to disperse and return to breed at distances beyond the study area.

Dispersal distance also was compared with the natal brood size (Fig. 4), including only birds banded as nestlings, and not as fledglings where a sib may have been overlooked, and only in nests where no brood-parasitic cowbird (Molothrus ater) survived to fledge and might have affected the condition of the young bunting. Mean dispersal distance did not vary with natal brood size (ANOVA, $F_{[3,104]}=1.39, P=0.25$, NS).

Arrival Times, Competition, and Occupancy of Territories Near the Natal Site.The place of settling might be limited by social interactions with other males if adults return earlier in the season than yearlings and reoccupy their former territories. Survival (or return) of resident first-year and adult males to the next year averaged $52.3 \%$ at the Reserve and $58.7 \%$ at Niles (Payne, 1989), and nearly half of the territories occupied by a male in the previous year were not reoccupied by him between years. Many yearlings returned and settled before the adults. For yearlings of known date of arrival and settling on the natal area, the distance between natal site and breeding ter- 


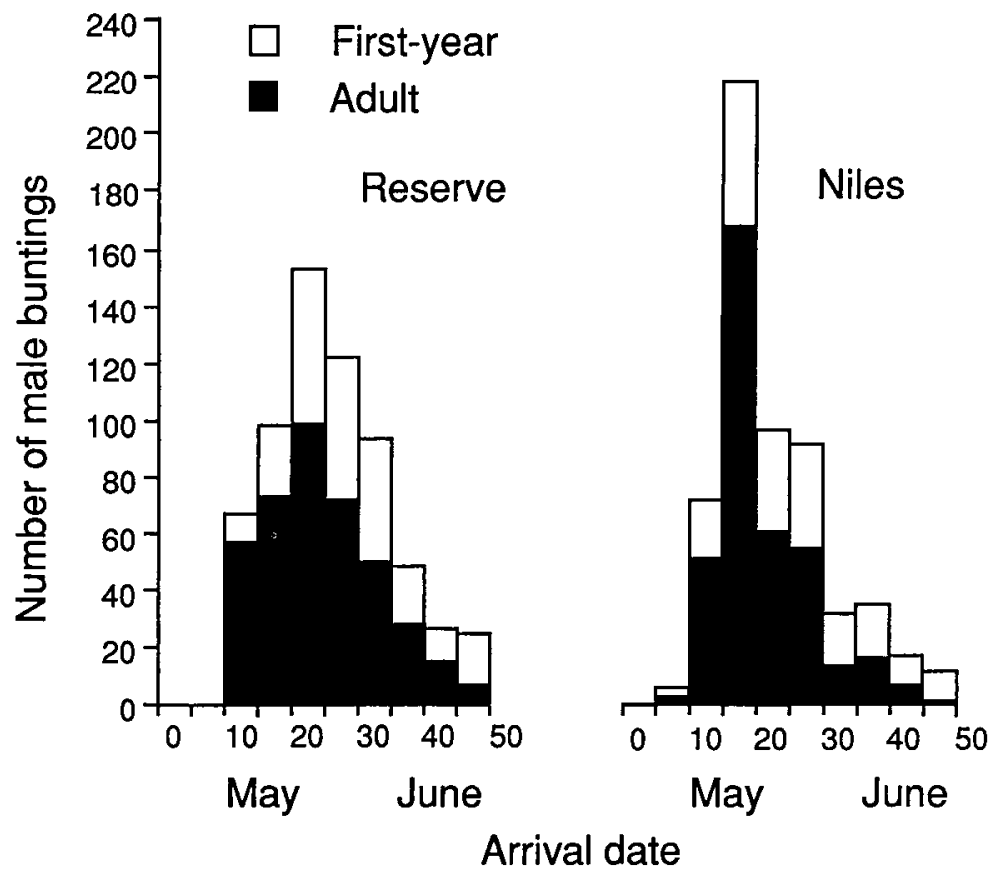

FIG. 5. Histogram of arrival times of adult and yearling male indigo buntings on their breeding area in spring. $1=1$ May.

ritory was not correlated with date of arrival $\left(N=65, b=0.006, r^{2}=0.03, F=2.19\right.$, NS). The territory sites appeared not to be limited by prior occupation by older males. One or more intervening sites were vacant in most cases and were not occupied until at least a week after arrival and settling.

The dates of arrival on territory in spring were compared to test whether the first-year males were limited in settling near their natal territory. The dates of arrival overlapped between age groups (Fig. 5). A male might have settled after occupying an earlier territory elsewhere, and within the study areas some males were observed to move from one territory to another. In males that arrived by 10 June during the intensively observed years 1979 to 1985 , the variance in arrival date among age groups was less than within groups (at the Reserve, variance among groups $R=0.069$; at Niles, $R=$ 0.084 , where $R$ is the covariance measure of among-group and total variance). Returning adults arrived earlier on average than yearlings (Reserve, 391 adults, mean arrival date from 1 May $=21.6 \pm 7.62 \mathrm{SD}$, and 215 first-year males, mean date $=24.5 \pm$ 7.25 SD, $F=21.7, P<0.001$; Niles, 377 adults, mean date $=18.2 \pm 7.02 \mathrm{SD}$, and 189 first-year males, mean date $=21.6 \pm$ 8.68 SD, $F=24.2, P<0.001)$. Because territories of males that did not return from the previous season were available and unoccupied by older males, nearly all returning yearling males could have settled closer to their natal site than expected if their sites of nesting were limited by social competition.

Female buntings are inconspicuous until they solicit matings and nest and their dates of arrival were unknown. It was not possible to determine prior occupation of territories between the natal site and the first breeding site for females. The annual survival of females was $33.1 \%$ at the Reserve, and $48.6 \%$ at Niles (Payne, 1989). About $15 \%$ of the breeding males have more than one female (Payne, 1982; Payne et al., 1988). Females appear to settle independently of whether another female is already on a male's territory, as the frequency distribution of females on male territories is described by a neutral Poisson model (Payne, 1983), suggesting an ideal free distribution in female settlement. The date of arrival of females is not closely related to their date of first nest- 
ing (Carey, 1982), so nesting date could not be used to estimate arrival time in the female buntings.

The observed dispersal distances from natal to breeding territory were compared with the distances expected under a condition of social limitation when a bird settles on its natal territory if it is unoccupied, or when it is occupied a bird settles on the next closest unoccupied territory (Waser, 1987). The probability $P_{n}$ of settling in the $n$th ring of territories is $P_{n}-\mathrm{q}(1-\mathrm{q})^{n}$, where $\mathrm{q}$ is the probability that the territory is unoccupied. In the adult indigo buntings, survival of both sexes from year to year is about 0.5 , the probability that a returning yearling would find its natal territory unoccupied is 0.5 , and in a hexagonal array the probability of at least one unoccupied territory in the first ring around it is greater than 0.99 . The model predicts that nearly all returning birds would settle within one territory of the natal site, but the observed mean was six or more, so the model does not predict the settling pattern of the buntings.

Avoidance of Inbreeding and Local Mate Competition. - Individuals may adjust their settling to avoid inbreeding or to avoid or seek out kin of the same sex. Two predictions can be made for birds that assess an area for the presence of their parents. If offspring actively avoid settling near their natal territory, as they might to avoid mating with a parent, then the natal dispersal distance should be greater for birds whose other-sex parent returned in the yearling year. Second, if parents discriminate between their own offspring and others, then the mean distance between natal site and first breeding site should differ when the parent of the same sex returned and when it did not.

Natal dispersal distances were compared in birds where one or both parents had been banded in relation to whether the parents returned (Fig. 6). The mean distance did not differ between yearling buntings whose parent returned and buntings whose parent did not return when the offspring and parent were the same sex (parent returned, $N=48$, mean distance $(\mathrm{m})=843 \pm 507 \mathrm{SD}$, parent did not return, $N=52$, mean $=785 \pm 457$ $\mathrm{SD}, t=0.72$, NS), or when offspring and parent were of the opposite sex (parent re-

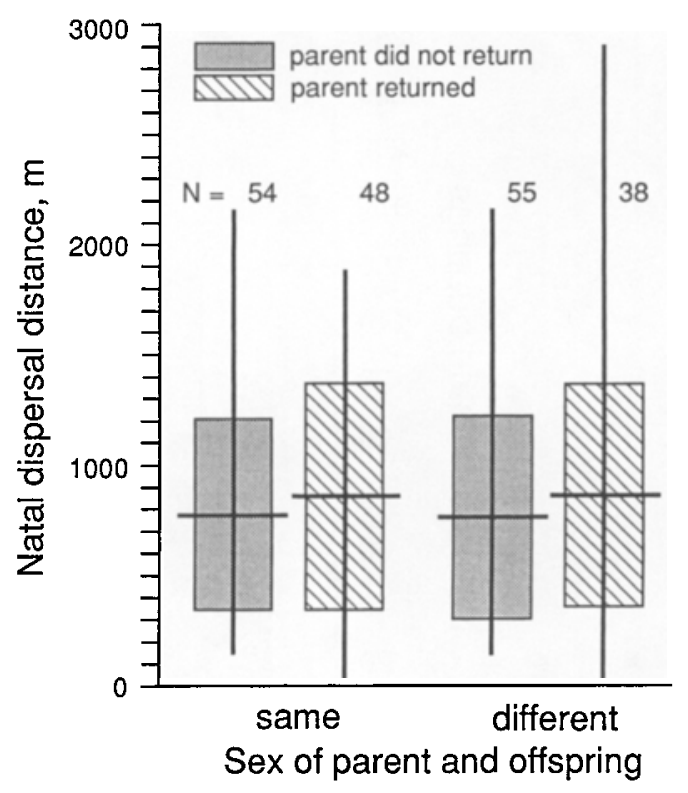

FIG. 6. Natal dispersal distance in relation to the presence of the parent in the natal area.

turned, $N=38$, mean $=878 \pm 523 \mathrm{SD}$, parent did not return, $N=55$, mean distance $=759 \pm 457 \mathrm{SD}, t=1.74$, NS). The parent did not appear to restrict or consent to the access of its offspring, nor did offspring appear to seek out or avoid the parent.

Similar predictions were tested to ask whether a bird assesses an area for the presence of a sib. If birds avoid settling near a sib of the opposite sex, as they might to avoid inbreeding, if birds seek kin for optimal inbreeding, or if birds are selectively excluded or socially tolerated by a sib of the same sex, then natal dispersal distances should differ for birds with a returning sib and with no sib, and the difference should vary depending on whether the sib is the same or the opposite sex. For yearling buntings, counting both full and half-sibs, and counting only the closest when more than one sib returned (Fig. 7), the mean distances from natal site to first breeding site did not differ in birds with a sib of the same or the opposite sex or with no known returning sibs (same sex, $N=16$, mean $=870 \pm 475$ $\mathrm{SD}$; other sex, $N=19$, mean $=647 \pm 469$ $\mathrm{SD}$; no sib, $N=79$, mean $=886 \pm 572 \mathrm{SD}$; ANOVA, $F_{[2,111]}=1.50, P>0.2$, NS).

Similarities among siblings in dispersal 


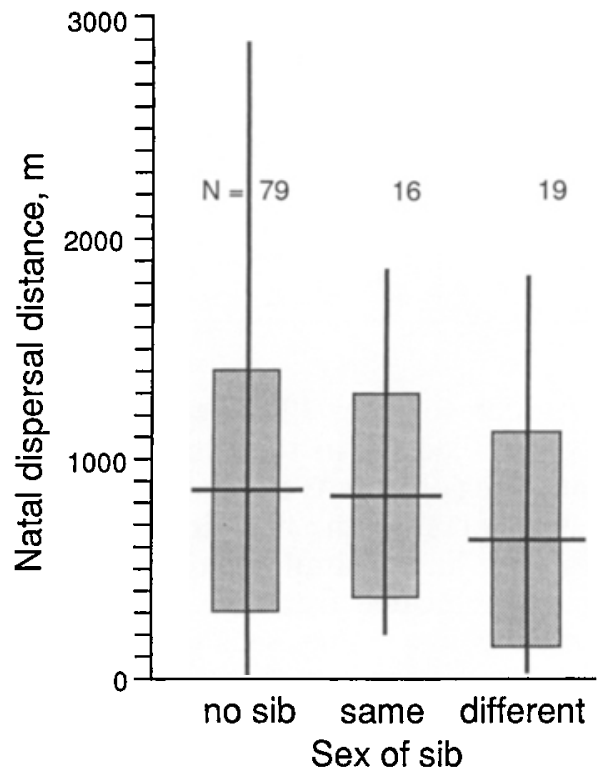

FIG. 7. Natal dispersal distance in relation to the presence of a sibling of the same or opposite sex, and to the absence of a sibling in the year of returning to the natal area in first-year indigo buntings.

distances might be due to heritability or to nongenetic factors such as birth date and location of the natal site within the study area. Dispersal distances did not vary among families where a mother had two or more returning young (ANOVA, $F_{[25,30]}=1.25$, NS; among-group variance $R=0.10$ ). Inference about heritability among patrilineally defined kin is less certain because of extra-pair fertilizations (Westneat, 1987; Payne and Payne, 1989).

Incidence and Effects of Inbreeding. - Inbreeding depends on demographic opportunity as well as on dispersal behavior. In buntings that returned to their natal area as yearlings, 52 could have bred with the parent $(N=40)$ or with a sibling or half-sib ( $N$ $=26$ ), or with both. The other 43 had no known close relatives of the opposite sex. For 20 additional yearlings the opposite-sex parent was unbanded and its survival was unknown.

Three yearlings mated with a close relative, two females with their father, and one male with his mother (who had mated with her father). In addition, a female in her second year mated with her father but in her first year mated with a male on a neigh- boring territory. All inbreeding yearlings returned to their natal territory or next to it.

One incestuous mating of a yearling with her father produced five fledged young, and a male offspring from the pair returned in the following year and bred. In two years his mates had six nests, 11 eggs that hatched, and three fledglings; the other nests failed owing to brood parasitism by cowbirds and to predation (Payne et al., 1987). In a second, a female mated with her father, then with a neighboring male. In the third, her son returned and mated with his mother; they had two nests. In the first nest the buntings hatched but the young starved and a cowbird was the only survivor, and in the second the young developed to day four then starved and the parents were not seen again. The observations showed no inbreeding depression, though with the low incidence of inbreeding, depression would be difficult to detect.

The proportion of females that mated with a male born in the same natal area was compared for all breeding females. At the Reserve, for 9 returning natal females, none of the 10 mates observed over their lifetimes were banded as nestlings. At Niles, for 49 females that bred in their natal area, 88 mates were identified and 15 of these were banded originally as nestlings. For the 35 females born in 1982 and later, 13 of 58 mates were banded as nestlings on the study area ( 2 of these males mated with two returning nestling females; 11 returning nestling males were involved). Nearly all indigo buntings that returned to their natal area and bred mated with a bird that had been born in another area.

An inbreeding coefficient $\Delta \mathrm{F}$ can be estimated from the proportion of birds that mated with a close relative. The coefficient is defined as the probability that a pair of alleles carried by the gametes that produced it are identical by genealogical descent; for example, $\Delta \mathrm{F}=0.25$ for parent and offspring (Falconer, 1981; Greenwood, 1987). The sum of coefficients for the first pairings of the returning nestlings is an estimate of the degree of inbreeding of the population. Assuming no significant kinship in the other 49 pairs, $\Delta F=0.014$. A second estimate was made from the 58 matings with different males by the 35 natal females (several 
females mated with more than one male during their lifetimes). This estimate was restricted to the years when nearly all nestlings had been banded for several previous years, so it provided known siblings as well as parents as potential mates. The two instances of inbreeding in the total of 58 give an estimate of $\Delta F=0.0086$, a low degree of inbreeding.

Population Structure: Immigration and Emigration. - The proportion of breeding birds that were born in the study area was determined at the Reserve in 1982-1984 and at Niles in 1983-1985. In each area the period began after four intensive years of banding nestlings. Birds banded as adults in marginal areas that were not banded earlier were omitted from the estimate as some may have been born locally before the study area was enlarged. The data include all banded males that were resident at least 28 days, the minimal time to mate and complete a breeding cycle to fledging, and all females. All banded females were observed to nest, but only about half of all females observed were captured and banded. Assuming that banded and unbanded females survive and switch mates at the same rate, the number of females in the study area was adjusted by reducing the proportion expected not to survive (determined in banded females, Payne, 1989) and the proportion of banded females that switched mates within a year (Table 1).

Most breeding buntings on both study areas were immigrants that were born outside the study area. At the Reserve, $1.6 \%$ of the breeding birds were born in the area, at Niles, $13.0 \%$. For both areas, $7.3 \%$ of the buntings bred in their natal area, and $92.7 \%$ were born outside the area.

The proportion of young born in the study area that dispersed and bred elsewhere should be similar to the proportion of breeding immigrants, at least at Niles where the number of breeding adults remained nearly constant (numbers decreased due to habitat changes at the Reserve), so that immigration and emigration could be similar. Survival from fledging to the first spring is unknown but probably is less than mean adult survival. Lifetime reproductive success (LRS) in leaving fledglings was 4.33 for each sex at Niles (Payne, 1989). This prob-
TABLE 1. Natal origin of indigo buntings in two breeding populations during three years.

\begin{tabular}{llrrr}
\hline \hline Area & Sex & $\begin{array}{c}N \text { local } \\
\text { bom }\end{array}$ & $\begin{array}{c}N \text { foreign } \\
\text { born }\end{array}$ & $\begin{array}{c}\text { \% Local } \\
\text { origin }\end{array}$ \\
\hline Reserve & male & 4 & 217 & 1.8 \\
& female & 3 & 215 & 1.4 \\
Niles & male & 27 & 189 & 12.5 \\
& female & 28 & 178 & 13.4 \\
\hline
\end{tabular}

ably underestimates LRS because $30 \%$ of the young fledged in the population were the offspring of parents that immigrated into the study area for the first time as secondyear birds, and a similar number of birds probably relocated from the study area to breed elsewhere in their second year (Payne, 1989). The observed proportion of breeding birds that were born on the study area $(13 \%)$ is much less than the $30-40 \%$ estimated to be alive as yearlings from the banded nestlings that fledged. Because the number of breeding birds was stable, most surviving nestlings must have gone elsewhere, and it appears that most buntings settle and breed at considerable distances from their natal site. The two distant recoveries of birds banded as nestlings give evidence of the occurrence of long-distance natal dispersal, though not the distribution of distances outside the natal area.

\section{Discussion}

A comparison of the predictions of inbreeding avoidance, social competition, and a neutral model of dispersal suggests that the variation in individual natal dispersal in the indigo buntings can best be accounted for in terms of a neutral model and is not explained by local processes of inbreeding and social competition. Natal dispersal of this migratory songbird maintains a dispersive, open population structure.

Proximate Causes of Variation in Dispersal Distance. - Social competition for local resources in the indigo buntings may occur in the form of territorial conflicts. In migrating populations the young do not remain near their birth site but return in a later season to a breeding area, and migration separates all individuals from their birth and breeding sites in time. In contrast, in resident populations the young from earlier broods may drive away the birds born later 
in the breeding season, which disperse, settle, and breed at greater distances from the natal site in some species (e.g., Kluyver, 1951, 1971; Dixon, 1956; Pinkowski, 1965; Dhondt and Hublé, 1968; Dhondt and Olaerts, 1981; Winkel, 1981; Winkel and Winkel, 1988; De Laet, 1985), though not in all species (Lowther, 1979; Matthysen and Schmidt, 1987). In the migratory indigo buntings, earlier-hatched birds tended to return further from the natal site, but not all migratory songbirds do this (Rheinwald and Gutscher, 1969; Haukioja, 1971). The difference in settling distance in buntings may be related to the longer time for juveniles to move and form a site attachment further from their natal site in the earlier-hatched birds (Nice, 1937; Löhrl, 1959; Haukioja, 1971).

Dispersal models that assume limited mobility of individuals and prior occupancy of the natal site by an older individual, especially the parent of the same sex (Murray, 1967; Waser, 1985, 1987), are more appropriate for resident than for migratory populations. The buntings that breed in their natal area undertake seasonal movements of more than $2,000 \mathrm{~km}$ and settle further from their natal site than would be explained by social competition for the closest available territory to their natal site. Most settled six territories or more from it. Because of mortality of adults from year to year and the overlap in time of arrival of yearlings and adults (nearly all variance in arrival time is within age groups), nearly all yearlings could have settled closer if the site of nesting were limited by social competition for territories around their natal site. The site where the young settle to breed may vary with juvenile dispersal in summer and territorial conflicts in spring as suggested by Bauer (1987), but the local demographic environment does not explain the majority of the observed dispersal distances, many territories from the natal site. The natal dispersal distances are greater than expected from the number of territories that were not reoccupied by returning adults in the indigo buntings. Greater distances than expected from adult mortality have also been observed in other migratory and resident songbirds (Drilling and Thompson, 1988; Tyler et al., 1990).
The population inbreeding coefficient $\Delta \mathrm{F}$ estimated from known genealogies is about 0.01 . The actual $\Delta F$ may be less, because the breeding immigrants from other areas are unlikely to be close kin. The low $\Delta \mathrm{F}$ in the migratory indigo buntings is similar to estimates in resident songbirds in which mating is random with respect to relatedness between mates (van Noordwijk and Scharloo, 1981; van Tienderen and van Noordwijk, 1988; Gibbs and Grant, 1989). The song types of fathers, sons, and the mates of daughters do not follow kinship lines and do not provide kinship markers in the buntings (Payne et al., 1987). The dispersal of yearlings from the natal site to a breeding site appears sufficient to explain the low incidence of inbreeding. A bias to return near the natal site and the survival of the parent account for the occasional parent-offspring mating, and the lack of observed sib-sib matings results from the lower chance of meeting of sibs due to independent dispersal and settling of yearlings from their natal site. Males and females return with equal incidence to their natal area and at equal distances from the natal site, so sex-limited dispersal is not necessary to explain the low incidence of inbreeding in these dispersive populations. In the reported sex-biased natal dispersal of songbirds in a review by Greenwood (1980), many cases were either statistically insignificant or unsupported by published data, or involved nonmigratory, mainly resident cooperatively breeding species. The low proportion of inbreeding is a consequence of dispersal, and no active inbreedingavoidance behaviors are indicated as suggested in some species (Blouin and Blouin, 1988).

The distribution of dispersal distances from the natal site and the inference from observed demographics that most buntings return to breed beyond their natal area suggest that buntings settle farther from the natal site than expected on the basis of social competition or avoidance of inbreeding with a close relative. The behavioral mechanisms that buntings use to return near to the natal site, and the differences between birds that return after migration and breed in their natal area and those that return far from it, are unknown. 
Genetic Consequences of Dispersal and Population Structure. - The genetic and evolutionary consequences of high dispersal rates include a low incidence of inbreeding and an open and outbred population (Mayr, 1963). Indigo buntings within a few $\mathrm{km}^{2}$ are not isolated from a larger regional population.

Outbreeding in the indigo buntings is effected by the mortality of kin, small family size, dispersal of returning nestlings to a territory away from their natal site, and the independent dispersal of kin. In the instances where a bunting returned within a territory or two of its natal site, a few in fact bred with the parent. Outbreeding then is a consequence of population demographics and movement, and not of active behavioral avoidance of kin or different dispersal of males and females.

Dispersal estimates of effective population sizes in songbirds generally are large $\left(N_{e}=10^{2}\right.$ to $10^{4}$, Barrowclough, 1980; Fleischer, 1983; Fleischer et al., 1984; Marzluff and Balda, 1989). These direct dispersal estimates are based on local returns and do not take into account birds that may have settled at greater distances, and the estimates are minimal. Local studies of most populations have extended beyond a few hundred ha mainly in colonial breeders with large numbers of birds in patchy sites, or in nestbox breeders. Searching at greater distances has revealed significant numbers at distances of $10^{2}$ to $10^{3} \mathrm{~km}$ (Kluyver, 1971; Rheinwald, 1975; Freer, 1979; Dhondt and Olaerts, 1981; Winkel and Winkel, 1988). In addition, few studies have shown the proportion of birds breeding in a local population that were born in the same area and those available were $50 \%$ or less, indicating substantial immigration and emigration (Nice, 1937; van Noordwijk, 1984; McCleery and Perrins, 1988; Clobert et al., 1988; Harvey et al., 1988; Marzluff and Balda, 1989; Winkel, 1989; Winkel and Frantzen, 1989). Effective population sizes of songbirds have also been estimated directly from dispersal data exclusive of local returns (Moore and Dolbeer, 1989), and indirectly from gene frequencies (Barrowclough, 1980, 1983; Fleischer, 1983; Avise et al., 1988) and karyotypic variation (Barrowclough and Shields, 1984). The large- scale dispersal survey and the two kinds of genetic surveys indicate large population sizes in birds and an evolutionary consequence of genetic cohesiveness within a species (Mayr, 1963).

\section{ACKNOWLEDGMENTS}

I thank the field assistants, particularly $S$. D. Kielb, L. L. Payne, D. F. Westneat, and J. Woods. Banding was carried out under U.S. Fish and Wildlife Service permit 20080. D. Bystrak of the Bird Banding Laboratory provided information on birds banded and recaptured. Amtrak permitted work on lands at Niles. The University of Michigan Museum of Zoology made available the facilities of the E. S. George Reserve, and D. J. Watt was helpful at Niles. T. M. Caro, $H$. L. Gibbs, G. E. Hill, N. K. Klein, L. L. Payne, L. J. Petit, H. W. Power, E. E. Werner, and D. F. Westneat commented on the manuscript. The research was supported by National Science Foundation grants.

\section{LITERATURE CTTED}

Avise, J. C., R. M. BALL, JR., AND J. ARNOLd. 1988. Current versus historical population sizes in vertebrate species with high gene flow: A comparison based on mitochondrial DNA polymorphism and inbreeding theory for neutral mutations. Molec. Biol. Evol. 5:331-344.

BARRowClough, G. F. 1980. Gene flow, effective population sizes, and genetic variance components in birds. Evolution 34:789-798.

1983. Biochemical studies of microevolutionary processes, pp. 223-261. In A. H. Brush and G. A. Clark, Jr. (eds.), Perspectives in Ornithology. Cambridge Univ. Press, N.Y.

Barrowclough, G. F., AND G. F. Shields. 1984. Karyotypic evolution and long-term effective population sizes in birds. Auk 101:99-102.

BATESON, P. 1983. Optimal outbreeding, pp. 257277. In P. Bateson (ed.), Mate Choice. Cambridge Univ. Press, Cambridge, UK.

BAUER, H.-G. 1987. Geburtsortstreue und Streuungsverhalten junger Singvögel. Vogelwarte 34:1532.

BLouIN, S. F., AND M. BLouIN. 1988. Inbreeding avoidance behaviors. Trends Ecol. Evol. 3:230-232.

CAREY, M. 1982. An analysis of factors governing pair-bonding period and the onset of laying in indigo buntings. J. Field Ornithol. 53:240-248.

Charlesworth, D., and B. Charlesworth. 1987. Inbreeding depression and its evolutionary consequences. Annu. Rev. Ecol. Syst. 18:237-268.

Chepko-SAde, B. D., AND Z. T. Halpin (eDs.). 1987. Mammalian Dispersal Patterns: The Effects of Social Structure on Population Genetics. Univ. Chicago Press, Chicago, IL. 
Clobert, J., C. M. Perrins, R. H. MCCleery, ANd A. G. GoSLER. 1988. Survival rate in the great tit Parus major in relation to sex, age and immigration status. J. Anim. Ecol. 56:287-306.

Clutton-Brock, T. H. 1989. Female transfer and inbreeding avoidance in social mammals. Nature 337:70-72.

DE LAET, J. V. 1985. Dominance and aggression in juvenile great tits, Parus major L. in relation to dispersal, pp. 375-380. In R. M. Sibley and R. H. Smith (eds.), Behavioural Ecology: Ecological Consequences of Adaptive Behaviour. Blackwell, Oxford, UK.

Dhondt, A. A., AND J. Hublé. 1968. Fledging date and sex in relation to dispersal in young tits. Bird Study 15:127-134.

Dhondt, A. A., AND G. OlaErTs. 1981. Variations in survival and dispersal with ringing date as shown by recoveries of Belgian great tits Parus major. Ibis 123:96-98.

Drxon, K. L. 1956. Territoriality and survival in the plain titmouse. Condor 58:169-182.

Dobson, F. S., AND W. T. JonEs. 1985. Multiple causes of dispersal. Am. Nat. 126:855-858.

DrILlING, N. E., AND C. F. ThOMPSON. 1988. Natal and breeding dispersal in house wrens (Troglodytes aedon). Auk 105:480-491.

ENDLER, J. A. 1977. Geographic Variation, Speciation, and Clines. Princeton Univ. Press, Princeton, NJ.

FaLCONER, D. S. 1981. Introduction to Quantitative Genetics. 2nd ed. Oliver and Boyd, London.

FLEISCHER, R. C. 1983. A comparison of theoretical and electrophoretic assessments of genetic structure in populations of the house sparrow (Passer domesticus). Evolution 37:1001-1009.

Fleischer, R. C., P. E. LowTHER, AND R. F. JohNSTON. 1984. Natal dispersal in house sparrows: Possible causes and consequences. J. Field Ornithol. 55:444456.

FreER, V. M. 1979. Factors affecting site tenacity in New York bank swallows. Bird-Banding 50:349357.

Fretwell, S. D., AND H. L. Lucas. 1969. On territorial behavior and other factors influencing habitat distribution in birds. Acta Biotheoretica 19:16-36.

Gauthreaux, S. A., JR. 1978. The ecological significance of behavioural dominance, pp. 17-54. In P. P. G. Bateson and P. H. Klopfer (eds.), Perspectives in Ethology, Vol. 3. Plenum Press, London.

GibBs, H. L., AND P. R. Grant. 1989. Inbreeding in Darwin's medium ground finches (Geospiza fortis). Evolution 43:1273-1284.

GreENwOOD, P. J. 1980. Mating systems, philopatry and dispersal in birds and mammals. Anim. Behav. 28:1140-1162.

- 1987. Inbreeding, philopatry and optimal outbreeding in birds, pp. 207-222. In F. Cooke and P. A. Buckley (eds.), Avian Genetics. Academic Press, N.Y.

Greenwood, P. J., P. H. Harvey, and C. M. Perrins. 1979. The role of dispersal in the great tit (Parus major): The causes, consequences and heritability of natal dispersal. J. Anim. Ecol. 48:123-142.

Harvey, P. H., M. J. StennING, and B. Campbell. 1988. Factors influencing reproductive success in the pied flycatcher, pp. 189-200. In T. H. CluttonBrock (ed.), Reproductive Success. Univ. Chicago Press, Chicago.

Haukioja, E. 1971. Short-distance dispersal in the reed bunting Emberiza schoeniclus. Ornis Fennica 48:45-67.

KLUYVER, H. N. 1951. The population ecology of the great tit, Parus m. major L. Ardea 39:1-135.

- 1971. Regulation of numbers in populations of great tits (Parus m. major). Proc. Adv. Study Inst. Dynamics Numbers Populations (Oosterbeek, 1970):507-523.

LöHRL, H. 1959. Zur Frage des Zeitpunktes einer Prägung auf die Heimatregion beim Halsbandschnäpper (Ficedula albicollis). J. Ornithol. 100:132140.

LoTKA, A. J. 1956. Elements of Mathematical Biology. Dover, N.Y.

LOWTHER, P. E. 1979. Growth and dispersal of nestling house sparrows: Sexual differences. Inland Bird Banding 51:23-29.

MacArthur, R. H., AND E. O. WIIson. 1967. The Theory of Island Biogeography. Princeton Univ. Press, Princeton, NJ.

MarzlufF, J. M., AND R. P. BaldA. 1989. Causes and consequences of female-biased dispersal in a flock-living bird, the pinyon jay. Ecology 70:316328.

MATTHYSEN, E., AND K. H. SchmidT. 1987. Natal dispersal in the nuthatch. Ornis Scand. 18:313-316.

MAYR, E. 1963. Animal Species and Evolution. Harvard Univ. Press, Cambridge, MA.

MCCleery, R. H., AND C. M. Perrins. 1988. Lifetime reproductive success of the great tit, Parus major, pp. 136-153. In T. H. Clutton-Brock (ed.), Reproductive Success. Univ. Chicago Press, Chicago, IL.

MOORE, J., AND R. AtI. 1984. Are dispersal and inbreeding avoidance related? Anim. Behav. 32:94 112.

MoOre, W. S., AND R. A. Dolbeer. 1989. The use of banding recovery data to estimate dispersal rates and gene flow in avian species: Case studies in the red-winged blackbird and common grackle. Condor 91:242-253.

MURRAY, B. G. 1967. Dispersal in vertebrates. Ecology 48:975-978.

NiCE, M. M. 1937. Studies in the life history of the song sparrow. I. Trans. Linn. Soc. N.Y. 1-247.

OkuBo, A. 1980. Diffusion and Ecological Problems: Mathematical Models. Springer Verlag, Berlin.

PAYNe, R. B. 1982. Ecological consequences of song matching: Breeding success and intraspecific song mimicry in indigo buntings. Ecology 63:401 -411 .

. 1983. Bird songs, sexual selection, and female mating strategies, pp. 55-90. In S. K. Wasser (ed.), Social Behavior of Female Vertebrates. Academic Press, N.Y.

. 1989. Indigo bunting, pp. 153-172. In I Newton (ed.), Lifetime Reproduction in Birds. Academic Press, London.

PAyne, R. B., AND L. L. PAYNe. 1989. Heritability estimates and behaviour observations: Extra-pair matings in indigo buntings. Anim. Behav. 38:457467.

Payne, R. B., L. L. Payne, AND S. M. Doehlert. 1987. 
Song, mate choice and the question of kin recognition in a migratory songbird. Anim. Behav. 35: $35-47$.

2. 1988. Biological and cultural success of song memes in indigo buntings. Ecology 69:104-117.

Payne, R. B., AND D. F. Westneat. 1988. A genetic and behavioral analysis of mate choice and song neighborhoods in indigo buntings. Evolution 42: 935-947.

PINKowsk, J. 1965. Overcrowding as one of the causes of dispersal of young tree sparrows. Bird Study $12: 27-33$.

Pusey, A. E. 1987. Sex-biased dispersal and inbreeding avoidance in birds and mammals. Trends Ecol. Evol. 2:295-299.

Ralls, K., P. H. Harvey, AND A. M. Lyles. 1986. Inbreeding in natural populations of birds and mammals, pp. 35-56. In M. Soulé (ed.), Conservation Biology: The Science of Scarcity and Diversity. Sinauer, Sunderland, MA.

Rhernwald, G. 1975. The pattern of settling distances in a population of house martins Delichon urbica. Ardea 63:136-145.

Rheinwald, G., AND H. Gutscher. 1969. Dispersion und Ortstreue der Mehlschwalbe (Delichon urbica). Vogelwelt 90:121-140.

Sellers, R. M. 1984. Movements of coal, marsh and willow tits in Britain. Ringing and Migration 5:7989.

ShIELd, W. M. 1982. Philopatry, Inbreeding, and the Evolution of Sex. State Univ. New York Press, Albany, NY.

STENSETH, N. C. 1984. Causes and consequences of dispersal in small mammals, pp. 132-159. In I. R. Swingland and P. J. Greenwood (eds.), The Ecology of Animal Movement. Clarendon Press, Oxford.

TAYLOR, R. A. J. 1980. A family of regression equations describing the density distribution of dispersing organisms. Nature 286:53-55.

TYLER, S. J., S. J. ORMEROD, AND J. M. S. LewIS. 1990. The post-natal and breeding dispersal of Welsh dippers Cinclus cinclus. Bird Study 37:18-23.
VAN NOORDWIJ, A. J. 1984. Problems in the analysis of dispersal and a critique on its 'heritability' in the great tit. J. Anim. Ecol. 53:533-544.

VAN NOORDWUK, A. J., AND W. SCHARLOO. 1981. Inbreeding in an island population of the great tit. Evolution 35:674-688.

van TIEnderen, P. H., AND A. J. vaN NoORDwiJk. 1988. Dispersal, kinship and inbreeding in an island population of the great tit. J. Evol. Biol. 1: 117-137.

WASER, P. M. 1985. Does competition drive dispersal? Ecology 66:1170-1175.

-1987. A model predicting dispersal distance distributions, pp. 251-256. In B. D. Chepko-Sade and Z. T. Halpin (eds.), Mammalian Dispersal Patterns: The Effects of Social Structure on Population Genetics. Univ. Chicago Press, Chicago, IL.

WeSTNEAT, D. F. 1987. Extra-pair fertilizations in a predominantly monogamous bird: Genetic evidence. Anim. Behav. 35:877-886.

WINKEL, W. 1981. Zum Ortstreue-Verhalten von Kohl-, Blau- und Tannenmeisen (Parus major, $P$. caeruleus und $P$. ater) in einem 325 ha grossen Untersuchungsgebiet. Vogelwelt 102:81-106.

- 1989. Zum Dispersionsverhalten und Lebensalter des Kleibers (Sitta europaea caesia). Vogelwarte $35: 37-48$.

Winkel, W., AND M. Frantzen. 1989. Ortstreue, Emigration und Lebensalter von Kohlmeisen (Parus major) im Braunschweiger Raum. Vogelwarte 35:64-79.

Winkel, W., AND D. Winkel. 1988. Zur Abwanderung von Kohl- und Tannenmeisen (Parus major, $P$. ater) eines Lärchen-Versuchgebietes. Vogelwarte 34:225-232.

WRIGHT, S. 1969. Evolution and the Genetics of Populations, Vol. II. Univ, Chicago Press, Chicago, IL. . 1978. Evolution and the Genetics of Populations, Vol. IV. Univ. Chicago Press, Chicago, IL.

Corresponding Editor: J. M. Ringo 